\title{
A study of some of the methods of urinary collection in children
}

\author{
NANCY K. CONN \\ From the Central Microbiological Laboratories, Edinburgh
}

SYNOPSIS Three methods of urine collection used currently in the diagnosis of urinary tract infection in children were studied. One hundred and fifty-two hospital patients were investigated: 92 by clean-catch method, 32 by the adhesive plastic bag technique, and 28 by suprapubic bladder aspiration. Results indicate that in the great majority of children a satisfactory diagnosis can be made on bacteriological grounds by the examination of specimens passed naturally and collected with care. In a minority of cases further investigation by such means as bladder aspiration may be indicated and this gives conclusive results.

To establish with certainty the presence of a bacteriuria significant of infection in children is both a difficult and important task. Care in urine collection is accepted as of crucial importance but doubt still remains as to the most reliable method applicable to children. The two main alternatives are collection by natural means and instrumentation. It is anticipated, however, that the latter method may be adopted only in a minority of cases. Certain aspects of the clean-catch and adhesive bag methods were studied in two wards of a children's hospital, and from the results of these, suprapubic bladder aspiration was carried out in a third ward on a selected group of cases.

\section{Materials and Methods}

In ward A clean-catch specimens with and without preliminary toilet were compared. Children of both sexes and all ages with symptoms in any way referable to urinary tract infection were examined before treatment. Two specimens were collected from each patient by a nurse. The urine was passed directly into a sterile kidney dish and transferred to a universal container. This was placed in a thermos cooling flask for transport to the laboratory where culture as described by Urquhart and Gould (1965) was carried out. The first specimen had no preliminary preparation (clean-catch urine). The second was preceded by swabbing of the genitalia and perineum with sterile wool soaked in $1: 800$ hypochlorite solution, cleansing with sterile saline, and drying with sterile wool. One hundred and five paired speci-

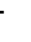




\begin{tabular}{|c|c|c|c|c|c|c|c|c|c|c|c|c|}
\hline \multirow[b]{3}{*}{ Group } & \multirow[b]{3}{*}{ Urine } & \multicolumn{5}{|l|}{ Males } & \multicolumn{5}{|c|}{ Females } & \multirow[t]{3}{*}{ Total } \\
\hline & & \multirow[t]{2}{*}{ Total } & \multicolumn{4}{|c|}{ Age Group (yr) } & \multirow[t]{2}{*}{ Total } & \multicolumn{4}{|c|}{ Age Group (yr) } & \\
\hline & & & $0-1$ & $1-3$ & $3-6$ & $6-14$ & & $0-1$ & $1-3$ & $3-6$ & $6-14$ & \\
\hline & $\begin{array}{l}\text { Number of paired } \\
\text { urines examined }\end{array}$ & 53 & 23 & 3 & 9 & 18 & 52 & 11 & 11 & 161 & 14 & 105 \\
\hline I & $\begin{array}{l}\text { Number showing no } \\
\text { growth (both } \\
\text { methods) }\end{array}$ & 29 & 5 & 3 & 8 & 13 & 25 & 1 & 6 & 9 & 9 & $\begin{array}{r}54 \\
(52 \%)\end{array}$ \\
\hline II & $\begin{array}{l}\text { Number showing } \\
\text { identical bacterial } \\
\text { counts (clean-catch } \\
\text { and treated) }\end{array}$ & 16 & 12 & 0 & 1 & 3 & 18 & 4 & 4 & 5 & 5 & $\begin{array}{r}34 \\
(32 \%)\end{array}$ \\
\hline III & $\begin{array}{l}\text { Number showing } \\
\text { lack of correspond- } \\
\text { ence between treated } \\
\text { and clean-catch }\end{array}$ & 8 & 6 & 0 & 0 & 2 & 9 & 6 & 1 & 2 & 0 & $\begin{array}{r}17 \\
(16 \%)\end{array}$ \\
\hline
\end{tabular}

Table I Bacteriological results of untreated and treated specimens in relation to age and sex

mens from 92 children were examined in this way.

In ward B the adhesive plastic bag technique was studied with particular reference to the problem of contamination. Fifty-six observations were made on 32 children (10 male and 22 female of whom 16 were under 1 year, 13 aged 1-2 years, and three aged 2-3 years). Three specimens were examined bacteriologically from each patient: (1) a dry swab of the interior of the bag before application; (2) a dry swab of the perineum of females and the prepuce of males to provide evidence of the commensal bacteria; (3) urine from the bag transferred to a universal container as soon as possible after voiding.

Urine was examined as in experiment $A$, while material from swabs 1 and 2 was plated on to blood agar and MacConkey media and incubated for 48 hours at $37^{\circ} \mathrm{C}$.

Where possible, it is wise practice to examine a series of specimens by either of these methods to increase the accuracy of diagnosis. But in some cases, equivocal or contradictory results make a

\begin{tabular}{|c|c|c|c|c|c|}
\hline \multicolumn{2}{|l|}{ Culture } & \multirow{2}{*}{$\begin{array}{l}\text { Male } \\
14\end{array}$} & \multirow{2}{*}{$\begin{array}{l}\text { Female } \\
42\end{array}$} & \multicolumn{2}{|c|}{ Total } \\
\hline Bag & $\begin{array}{l}\text { Number from which no } \\
\text { organisms isolated }\end{array}$ & & & 56 & $(100 \%)$ \\
\hline \multirow[t]{2}{*}{ Perineal } & $\begin{array}{l}\text { Number with no organisms } \\
\text { isolated from prepuce or } \\
\text { perineum }\end{array}$ & 5 & 16 & 21 & $(37 \%)$ \\
\hline & $\begin{array}{l}\text { Number with mixed surface } \\
\text { organisms }\end{array}$ & 9 & 26 & 35 & $(63 \%)$ \\
\hline \multirow[t]{4}{*}{ Urine } & Number with no growth & 4 & 7 & 11 & $(20 \%)$ \\
\hline & $\begin{array}{l}\text { Number with bacterial } \\
\text { counts }<10^{5} \text { organisms } / \mathrm{ml}\end{array}$ & 9 & 29 & 38 & $(68 \%)$ \\
\hline & $\begin{array}{l}\text { Number with counts of } \\
10^{5} \text { organisms } / \mathrm{ml}\end{array}$ & 1 & 3 & 4 & $(7 \%)$ \\
\hline & $\begin{array}{l}\text { Number with counts of } \\
>10^{5} \text { organisms } / \mathrm{ml}\end{array}$ & nil & 3 & 3 & $(5 \%)$ \\
\hline
\end{tabular}

Table II Comparative results of bacteriological examination of 56 bags, perinea, and urines conclusion impossible and further repetition nfmy only exaggerate this doubt. It seems reasonabje then to proceed to some form of instrumentation. In ward C, 28 such untreated children (19 fema仿es and nine males) were investigated by suprapubic bladder aspiration as described by Pryles, Atkộ, Morse, and Welch (1959). Of these patients, 14 females and eight males were under 2 years age. The result of the most recent clean-cateh or bag specimen of each was used as a control.

\section{Results and Comment}

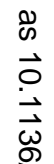

The purpose of experiment A was to show if results of untreated and treated specimens colincided sufficiently to give an accurate bacterifological diagnosis, and, if not, to show if preliminatsy cleansing gave better results. A remarkable degrete of consistency was in fact demonstrated (Table 1 ). In 54 instances there was good evidence that infection was not present. A further 34 gałe identical results (in regard to both species aogd count), of which 19 were $10^{4}$ organisms $/ \mathrm{ml}$, a d all but one mixed and was not therefore considered significant. Discrepancies between treated a $\vec{q}$ untreated specimens existed in 17 cases. Twelve of these showed a tenfold difference in count (the minimum which could be reliably detected by the cultural method used), the species isolated bei alike in all cases. The remaining five had fo growth from one specimen and a mixed growgh from the other. In interpreting the significanee of these bacterial counts three points were comsidered simultaneously: the total count, the purity of the growth, and the identity of the isolate. On this basis a fairly reliable diagnosis was reached when the counts were related to whise blood cell excretion and general clinical assessment. In all, 32 paired samples gave resufts suggestive of infection. Of these 13 (from $\$ 2$ children, four in group II and nine in group B. I in Table I) had a count of $10^{5}$ organisms $/ \mathrm{ml}$ in ofe specimen -an equivocal result. Nineteen had a a count of $10^{6}$ organisms $/ \mathrm{ml}$ or more (11 in group9I and eight in group III) and were eventualiby accepted as cases of infection.

As regards the value of antiseptic toilet, 8 paired specimens gave identical results. Of the 17 showing some discrepancy, higher courts were obtained by the treated method in 11, nime of which showed multiple species, while a higher count was obtained by the clean-catch methoden six, five of which consisted of a single species. It would appear that toilet made little differene to the result, any difference being in favour $\mathbb{B} f$ the clean-catch method. This finding agrees with the view of Turner (1961) that in a series of antenatal patients preliminary cleansing gave no better results.

As was expected, less conclusive results we reached from experiment B (Table II), sincegă 
applied to the age group most difficult to diagnose. Results showed that contamination could not be attributed to the bags themselves and that the perineal surfaces were not the consistent source of contamination. Of 21 patients whose perineal swabs yielded no growth, 16 had growths in the urine, and of 11 with no growth in the urine, six showed organisms present in the perineum: in a further six cases the species from the local sites were entirely different from those isolated in the urine. Thus in over $50 \%$ there was no demonstrable causal relationship between the two. Only seven results (from five patients) were suggestive of significant bacteriuria, ie, $10^{5}$ organisms $/ \mathrm{ml}$ or more. Of these, three (from two patients) gave counts of $10^{6}, 10^{6}$, and $10^{7}$ organisms $/ \mathrm{ml}$ in a single species and were associated with no growth from the perineal swabs and were regarded as significant of infection. The remain- ing four (from three infants under 1 year of age) $\overline{\overline{\bar{z}}}$ had counts of $10^{5}$ organisms $/ \mathrm{ml}$ and were consid- 0 ered of doubtful significance. Thirty-eight with counts of $<10^{5}$ organisms $/ \mathrm{ml}$ were bacterio- logically not considered significant since 20 con- $\overrightarrow{\vec{F}}$ sisted of multiple species and 18 a single species at $t^{\frac{\rho}{9}}$ $10^{4}$ organisms $/ \mathrm{ml}$ or less. Overall, the small number of high bacterial counts is worthy of emphasis $\frac{\overline{\bar{c}}}{\bar{s}}$ as it suggests that even if some delay occurs in $\vec{\sigma}_{\bar{\sigma}}$ the removal of the bag after the passing of the 0 specimen the proliferation of organisms is notes of great account when the specimen is maintained $-\overrightarrow{-}$ at a low temperature. These results contrastmarkedly with those of Braude, Forfar, Gould, $\vec{\omega}$ and McLeod (1967) who reported counts of $10^{5}$ organisms $/ \mathrm{ml}$ in $50 \%$ and $10^{6}$ organisms $/ \mathrm{ml}$ in $15 \%$ of normal children under 2 years of age.

The results of bladder aspiration in all examinedcases were clear-cut (Table III). In the five positive ${ }_{-}^{\infty}$

\begin{tabular}{|c|c|c|c|c|c|}
\hline $\operatorname{Sex}$ & Age & $\begin{array}{l}\text { Bag or Clean-catch Urine Count } \\
\text { (organisms/ml) }\end{array}$ & Source of Specimen & $\begin{array}{l}\text { Aspirate Count } \\
\text { (organisms } / m l)\end{array}$ & $\begin{array}{l}\text { Time between } \\
\text { Specimens (days) }\end{array}$ \\
\hline $\mathbf{F}$ & $2 \mathrm{mth}$ & Proteus Esch. coli (2 strains) $10^{\circ}$ & Bag & Esch. coli $10^{3}$ & Same day \\
\hline $\mathbf{M}$ & $3 \mathrm{mth}$ & Esch. coli $10^{7}$ & Bag & Esch. coli $10^{\mathrm{s}}$ & Same day \\
\hline $\mathbf{F}$ & $8 \mathrm{yr}$ & Esch. coli $10^{6}$ & Clean catch & Esch. coli $10^{\circ}$ & Same day \\
\hline $\mathbf{F}$ & 8 yr & Coliform bacilli $10^{7}$ & Clean catch & Coliform bacilli $10^{\circ}$ & Same day \\
\hline$F \mathbf{F}$ & $10 \mathrm{yr}$ & Proteus $10^{8}$ & Clean catch & Proteus $10^{7}$ & Same day \\
\hline $\mathbf{F}$ & $1 \mathrm{mth}$ & Esch. coli 10 & Bag & No growth & 2 \\
\hline $\mathbf{M}$ & 2 wk & $\begin{array}{l}\text { Esch. coli } 10^{4} \\
\text { Staph. pyogenes } 10^{\circ}\end{array}$ & Bag & No growth & 4 \\
\hline $\mathbf{F} \mathbf{I}$ & $7 \mathrm{mth}$ & Proteus $10^{5}$ & Bag & No growth & Same day \\
\hline $\mathbf{F}$ & $11 \mathrm{yr}$ & $\begin{array}{l}\text { Esch. coli } \\
\text { Enterococcus }\end{array}$ & Clean catch & No growth & Same day \\
\hline M I: & 3 wk & Esch. coli $10^{7}$ & Bag & No growth & 1 \\
\hline $\mathbf{M}$ & $3 \mathrm{yr}$ & Esch. coli 8000 & Clean catch & No growth & Same day \\
\hline $\mathbf{F}$ & 2 wk & $\begin{array}{l}\text { Esch. coli } \\
\text { Proteus } \\
\text { Enterococcus }\end{array}$ & Bag & No growth & 5 \\
\hline $\mathbf{M}$ & $2 \mathrm{mth}$ & $\begin{array}{l}\text { Ps. pyocyanea } \\
\text { Proteus } \\
\text { Esch. coli }\end{array}$ & Bag & No growth & 4 \\
\hline $\mathbf{F}$ & 5 days & Enterococcus $10^{5}$ & Bag & No growth & 3 \\
\hline $\mathbf{F}$ & $16 \mathrm{mth}$ & Mixed coliform bacilli & Bag & No growth & 2 \\
\hline $\mathbf{F}$ & $9 \mathrm{mth}$ & Proteus $10^{7}$ & Bag & No growth & 2 \\
\hline $\mathbf{M}$ & 2 wk & Esch. coli $10^{5}$ & Bag & No growth & Same day \\
\hline $\mathbf{M}$ & $2 \mathrm{mth}$ & Proteus (small nos.) & Clean catch & No growth & 2 \\
\hline $\mathbf{F}$ & $9 \mathrm{mth}$ & $\begin{array}{l}\text { Esch. coli } \\
\text { Proteus } \\
\text { Enterococcus }\end{array}$ & Bag & No growth & 2 \\
\hline $\mathbf{M}$ & 2 wk & Esch. coli $10^{5}$ & Clean catch & No growth & Same day \\
\hline $\mathbf{F}$ & $3 \mathbf{w k}$ & $\begin{array}{l}\text { Esch. coli } \\
\text { Enterococcus }\end{array}$ & Bag & No growth & Same day \\
\hline $\mathbf{F}$ & $3 \mathrm{mth}$ & $\begin{array}{l}\text { Esch. coli } \\
\text { Proteus }\end{array}$ & Bag & No growth & 3 \\
\hline $\mathbf{F}$ & $3 \mathrm{mth}$ & Esch. coli $10^{5}$ & Bag & No growth & 4 \\
\hline $\mathbf{F}$ & 2 wk & $\left.\begin{array}{l}\text { Esch. coli } \\
\text { Proteus } \\
\text { Enterococcus }\end{array}\right\}$ & Bag & No growth & Same day \\
\hline $\mathbf{F}$ & $1 \mathrm{mth}$ & Coliform bacilli $10^{?}$ & Bag & No growth & Same day \\
\hline $\mathbf{M}$ & $1 \mathrm{mth}$ & Esch. coli 10 & Bag & No growth & 3 \\
\hline $\mathbf{F}$ & $3 \mathrm{mth}$ & 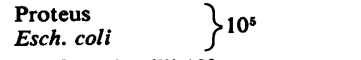 & Bag & No growth & 1 \\
\hline $\mathbf{F}$ & $2 \mathrm{yr}$ & Coliform bacilli $10^{5}$ & Bag & No growth & 4 \\
\hline
\end{tabular}


cases, the species isolated from both the cleancatch and aspirate specimens were alike although the count in the latter was slightly lower (approximately $\left.10^{1}\right)$. The remaining 23 proved to be negative. This finding supports the belief that in young children growths of mixed organisms in varying numbers are mainly due to contamination and that in general there is a tendency to false positives from urine specimens collected by standard methods.

\section{Conclusion}

From the studies A and B it is clear that a considerable proportion of children can be confidently diagnosed by the methods at present practised. There will inevitably be some children, particularly those under 2 years of age, who give puzzling results, on whom it seems justifiable to carry out a further diagnostic procedure. Suprapubic aspiration has proved valuable in these doubtful cases, as shown in study $\mathrm{C}$.

I wish to thank Drs D. M. Douglas, W. M. McCrae, and J. W. Farquhar, consultant paediatricians, whose patients were investigated as described.
References

Braude, H., Forfar, J. O., Gould, J. C., and McLeod, J. W. (1967\% Cell and bacterial counts in the urine of normal infants and children. Brit. med. J., 4, 697-701.

Pryles, C. V., Atkin, M. D., Morse, T. S., and Welch, K. J. (1959). Comparative bacteriological study of urine obtainent from children by percutaneous suprapubic aspiration the bladder and by catheter. Pediatrics, 24, 983-991.

Turner, G. C. (1961). Bacilluria in pregnancy. Lancet, 2, 1062-1064

Urquhart, G. E. D., and Gould, J. C. (1965). Simplified techniqu for counting the number of bacteria in urine and othe fluids. J. clin. Path., 18, 480-481.

\section{Reports and Bulletins prepared by the Association of Clinical Biochemists}

The following reports and bulletins are published by the Association of Clinical Biochemists. They may be obtained from The Administrative Office, Association of Clinical Biochemists, 7 Warwick Court, Holborn, London, W.C.1. The prices include postage, but airmail will be charged extra. Overseas readers should remit by British Postal or Money Order. If this is not possible, the equivalent of $10 \mathrm{~s}$. is the minimum amount that can be accepted.

\section{SCIENTIFIC REPORTS}

3 Automatic Dispensing Pipettes. An assessment of 35 commercial instruments 1967 P. M. G. BROUGHTON, A. H. GOWENLOCK, G. M. WIDDOWSON, and $\mathrm{K}$. A. AHLQUIST 10s

\section{TECHNICAL BULLETINS}

9 Determination of Urea by AutoAnalyzer November 1966 RUTH M. HASLAM 2s 6d

10 Filter Fluorimeters. A comparative list of 14 instruments March 1967 HANNELORE BRAUNSBERG (Re-issued in response to demand. Text still valuable, list now out of date) $5 \mathrm{~s}$
11 Determination of Serum Albumin by AutoAnalyzer using Bromocresol Green October 1967 B. E. NORTHAM and G. M. WIDDOWsON 2s 6d

12 Control Solutions for Clinical Biochemistry February 1968 P. M. G. BROUGHTON 2s 6d

13 An assessment of the Technicon Type II Sampler Unit March 1968 B. C. GRAY and G. K. MCGOWAN 1s 6d

14 Atomic Absorption Spectroscopy. An outline of its Principles and a Guide to the Selection of Instruments May 1968 J. B. DAWSON and P. M. G. BROUGHTON $4 \mathrm{~s}$
15 A Guide to Automatic Pipettes (2nd edition) June 1968 P. M. G. BROUGHTON $5 \mathrm{~s}$

16 A Guide to Automation in Clinical Chemistry May 1969 P. M. G. BROUGHTON $12 \mathrm{~s} 6 \mathrm{~d}(\$ 1.50)$

17 Flame Photometers (2nd edition) 1969 P. WILDING 12s 6d (\$1.50) 